\title{
TERRORISM AND THE CRIME OF AGGRESSION UNDER THE ROME STATUTE
}

\author{
Fajri Matahati Muhammadin* \\ International Law at the International Undergraduate Program, \\ Fakultas Hukum Universitas Gadjah Mada \\ Jalan Sosio Yustisia Nomor 1, Bulaksumur, Yogyakarta, D.I. Yogyakarta 55281
}

\begin{abstract}
Terrorism seems to be accepted as a grave act of international concern, but has not yet been accommodated explicitly in the International Criminal Court (ICC). This article explores the prospect of including terrorism under the crime of aggression in cases transcending boundaries, by examining whether terrorism can fit into its' elements. While terrorism can be conducted by state and non-state actors, it will be shown that it is possible for states committing terrorism to have their officials prosecuted for the crime of aggression. For the more infamous terrorism by non-state actors, however, do not seem to satisfy the required elements.
\end{abstract} Keywords: crime of aggression, terrorism, rome statute.

\section{Intisari}

Terorisme sudah diterima sebagai kejahatan yang menjadi perhatian internasional, tetapi belum diakomodasi secara eksplisit dalam hukum pidana internasional melalui Mahkamah Pidana Internasional (ICC). Artikel ini akan mengamati kemungkinan memasukkan terorisme dalam tindak pidana agresi, terutama dalam kasus terorisme yang melampaui batas-batas Negara. Artikel ini akan mengamati konsep tindak pidana agresi dalam Statuta Roma, dan melihat apakah terorisme dapat memenuhi unsur-unsurnya. Ternyata walaupun terorisme oleh actor non-negara lebih terkenal, tapi konsep terorisme dapat memuat terorisme oleh Negara juga. Akan dijelaskan bagaimana kejahatan agresi bisa jadi dikenakan pada terorisme oleh Negara, tetapi justru tidak pada terorisme oleh aktor non-negara.

Kata Kunci: tindak pidana agresi, terorisme, statuta roma.

\section{Pokok Muatan}

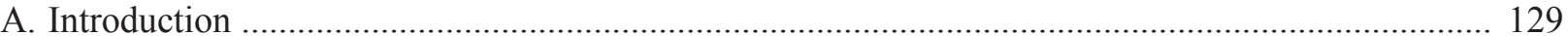

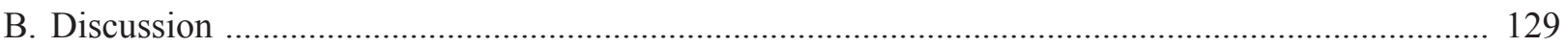

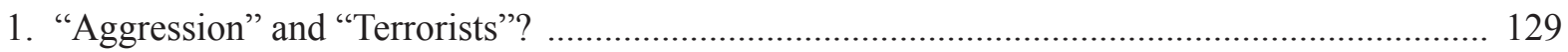

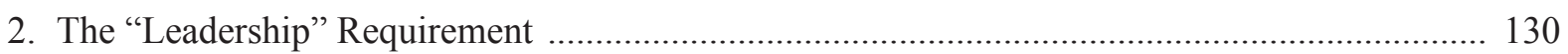

3. "Manifest Violation of the UN Charter" Requirement ........................................................... 136

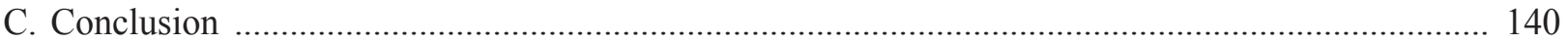




\section{A. Introduction}

Terrorism has been a threat to the international world for quite a while, and has become a new phenomenon. The 9/11 incident was even declared as a breach to international peace through UN Security Council (UNSC) Resolutions No. 1368 and 1373 (2011). However, the crime of terrorism has yet to find its way in international criminal law instruments. As one can observe in Article 5-8bis of the Rome Statute (ICCSt), there is no apparent reference to acts of terrorism. Does this mean that terrorism exists in a vacuum in international criminal law?

The legal problem discussed in this essay is: can the acts of terrorism classify under the crime of aggression under Article 8bis of the ICCSt? To answer this legal problem, one must first clarify the concept of "aggression" and "terrorism". From such clarification, it will be found that there can be two types of possible perpetrator of terrorism i.e. state and non-state actors. This will beg another legal problem: what are the consequences of difference in character of each type of perpetrator according to the ICCSt provisions regarding the Crime of Aggression? This essay will discuss the prospects and problems in prosecuting both types of terrorism before the ICC.

\section{B. Discussion}

\section{1. "Aggression" and "Terrorists"?}

\section{a. The Crime of Aggression}

An 'act of aggression' is defined in Article 8bis(2) of ICCSt as "[...] the use of armed force by a State against the sovereignty, territorial integrity or political independence of another State, or in any other manner inconsistent with the Charter of the United Nations". The Crime of Aggression itself in Article 8bis (1) essentially contains three conjunctive elements: (a) the involvement of the defendant towards that act of aggression, (b) the "leadership" requirement, and (c) whether the act of aggression is a manifest breach of the UN Charter. The Elements of Crime of the Crime of Aggression breaks into five elements to also incorporate the elements of "violation of sovereignty, territorial integrity, and political independence" which comes from the definition of the act of aggression in Article 8bis(2), and a "mental element".

The crime of aggression is a breach of jus ad bellum (legality of the use of force) which is separate from the jus in bello (lawful conducts of war). ${ }^{1}$ However, the actual relation may seem attached to each other. The horrors within the war are aggravating factors that consequently come with the starting of a war (i.e. aggression). ${ }^{2}$ Not to mention that not all acts of aggression will actually threaten international peace and security, ${ }^{3}$ and it is the assessment of inter alia gravity and scale that will determine whether the act of aggression to be processed in the ICC (as per Article $8 b i s(2)$ of the ICCSt).

\section{b. Terrorists and Terrorism}

It is plain enough to see that a 'terrorist' is one who commits acts of 'terrorism'. There have been many attempts to define the acts of terrorism, which all of them would have their own difficulty. It is so much easier to point at a certain act as an act of terror once we have seen it, but classifying it into a legal act would present more difficulties. ${ }^{4}$ Numerous instances would easily (popularly) be classified as terrorist attacks, e.g. the IRA

Marco Sassoli et al,. 2006, How Does Law Protect in War: Volume I (Outline of International Humanitarian Law) Third Edition, International Committee of the Red Cross, Geneva, pp. 14-15.

See Paras 2-3 of the Preamble of the ICCSt, see also: M. Cherif Bassiouni, "International Crimes: Jus Cogens and Obligatio Erga Omnes", Law and Contemporary Problems, Vol. 59, No.4, 1996, p.70.

Ibid.

4 Jacqueline S. Hodgson and Victor Tadros, "The Impossibility of Defining Terrorism", New Criminal Law Review: An International and Interdisciplinary Journal, Vol. 16, No. 3, August, 2013, p. 495. 
bombing in 1984, the 9/11 Incident in 2001, the Bali Bombing in 2002, etc, would easily classify as acts of terror. ${ }^{5}$

As a matter of law, though, there are numerous definitions of "terrorism", both in national and as international instruments. ${ }^{6}$ No single definition has been universally agreed upon, ${ }^{7}$ but there are two general elements that are common to all definitions of terrorism, namely: objective element (mainly the use of physical violence), and subjective element (the intention to create terror and fear, or coerce governments/ international organisations).$^{8}$

The aforementioned definition covers acts that are not normally be referred to as terrorism, e.g. the Iraq invasion (this will be explained later). ${ }^{9}$ However, this may generally be the best elements of a definition. This essay will use that together with examples from incidents that are commonly labelled as terrorist acts.

In addition, since the act of aggression involves transgressing "[...] sovereignty, territorial integrity, or political independence $[\ldots]{ }^{10},{ }^{10}$ acts of terrorism committed by actors within the state's territory will not be analysed. ${ }^{11}$

In order to answer whether acts of terrorism can be classified as a Crime of Aggression, the five elements of the crime as prescribed in the Elements of Crime should be fulfilled. However, there are a few elements that will be assumed to be satisfied in this essay.
The element of involvement (planning, preparing, initiating, or execution) is assumed to be satisfied, as this essay will focus on terrorists that are already assumed to be directly involved in the actions. The element of transgressing sovereignty (together with territorial integrity and political independence, the three as alternatives) are assumed to be satisfied as well, as it has been mentioned that this essay will eliminate terrorist acts conducted from within a State's territory. The mental element (awareness of the transgressing sovereignty) is also assumed to be satisfied, because the terrorists are assumed to have deliberately planned such kind of transgression.

It is the remaining two elements that will be shown to have some extent of controversy to be explored in this essay: the "leadership" requirement, and the 'manifest breach' test.

\section{The "Leadership" Requirement}

Article $8 b i$ s of the ICCSt defines the crime of aggression as an act of aggression committed " [...] by a person in a position effectively to exercise control over or to direct the political or military action of a State [...]". This is also the second element of the Crime of Aggression in the ICC Elements of Crime.

\section{a. De Jure Control}

A simple reading of the aforementioned provision would result in a conclusion that people who have formal positions in a State, with authority to control over the armed forces of that State, can commit a crime of aggression. One would easily think of

National: UK Terrorism Act 2000, Indonesian Anti-Terrorism Law No. 15 of 2003, etc, International: European Convention on the Suppression of Terrorism (1977), UN General Assembly (UNGA) Resolution No. 53 (1995), etc

Angela Hare, "A New Forum for the Prosecution of Terrorists: Exploring the Possibility of the Addition of Terrorism to the ICCSt's Jurisdiction", Loyola University Chicago International Law Review. Vol. 8, No.1, 2010, p. 97.

Christian Walter, "Defining Terrorism in National and International Law", in Christian Walters et al, 2004, Terrorism as a Challenge for National and International Law: Security versus Liberty? Sprinter, Heidelberg, pp. .42-43.

Jacqueline S. Hodgson and Victor Tadros, Op.cit., p.501.

Article $8 b i s(2)$ of the ICCSt.

Such as the Bali Bombing by the Indonesian Jamaah Islamiyah, although there may be some links to Al-Qaeda. See also, Muhammad Haniff bin Hassan, "Imam Samudra's Justification for Bali Bombing", Studies in Conflict and Terrorism, Vol. 30, Iss.12, 2007, pp.1034-1035, 10421043. 
Ayman Al-Zawahiri of Al-Qaeda (AQ), or Abu Bakar Baashir of the Jemaah Islamiyah when it comes to terrorist leaders. However, these names do not exercise any control of any military of any states, therefore any of their acts cannot easily qualify as an act of aggression.

\section{1) Terrorism by State?}

Is it, then, possible for a state to commit an act of terrorism? In 1992, the UN Security Council (UNSC) issued Resolution 748 (1992), to demand Libya to "[...] commit itself definitively to cease all forms of terrorist action [...]". The wording suggests that Libya has been committing acts of terrorism.

Some legislation may suggest this conclusion. The UK Terrorism Act provides an "action based" definition of terrorism describing acts constituting an act of terror, but not specifying who can perpetrate it. ${ }^{12}$ This is unlike the Indonesian Anti-Terrorism Law No. 15 of 2003 that specifies that only persons can commit act of terrorism. ${ }^{13}$

The Lockerbie incident, labelled as an act of terrorism, ${ }^{14}$ was attributed to Libya since UNSC Resolution 731 (1992) and then 748 (1992). Further, in 2011, the former justice minister of Libya mentioned that Ghaddafy actually personally ordered the act of terrorism in the Lockerbie incident. As note: this minister was a defector during the civil war, the claim was not investigated, and Ghaddafy himself denied giving such orders. $^{15}$
Assuming for argument sake that Ghaddafy actually did gave such orders, this is one very straightforward example of a person in effective control over a state (and its military power), committing an act of terrorism. Although, the Lockerbie incident does not constitute as an act of aggression which requires the aircraft attacked to be a military aircraft ${ }^{16}$ while the Pan Am Air 103 was a commercial flight.

The invasion to Iraq in 2003 may serve as an elusive example of acts of terror in form of aggression committed by a State. ${ }^{17}$ This invasion was clearly an act of violence both to the sovereignty of Iraq as well as the lives and property of the Iraq civilians (satisfying the objective element). ${ }^{18}$ Further, the purpose of the invasion was to coerce the Iraq government to commit certain acts (in this case, allegedly to obey UNSC resolutions or to institute democracy, etc, will be further explained later), satisfying the subjective element. ${ }^{19}$

The UK was involved in the invasion, ${ }^{20}$ while the UK Terrorism Act 2000 mentions the same subjective element in Section 1(1)(b)-(c), while the objective element in Section 1(2) is met (serious violence against a person or property, endangering a person's life, serious risk to health or safety of the public, etc). This might mean that the UK, under its' own law, committed an act of terror in the invasion to Iraq.

In a national law regime, one may propose to exclude official state's acts so

Steven Stottlemyre, "Libya and the International System: Retracing the Aftermath of the Lockerbie Bombing", Digest of Middle East Studies, Vol. 20, No.1, May, 2011, pp.54-55.

15 BBC, "Colonel Gaddafi 'ordered Lockerbie bombing", http://www.bbc.co.uk/news/uk-scotland-south-scotland-12552587, accessed on 6 April 2014.

16 Article 8 bis(2)(d) of the ICCSt

Jacqueline S. Hodgson and Victor Tadros, Op.cit., p.501.

BBC, "Iraq War in Figures", http://www.bbc.co.uk/news/world-middle-east-11107739, accessed on 6 April 2014.

19 Mathew Gillet, "The Anatomy of an International Crime of Aggression at the International Criminal Court", International Criminal Law Review, Vol. 13, No. 4, 2013, pp.848-849.

20 The Telegraph, "Iraqi War: Timeline of Tony Blair's Role", http://www.telegraph.co.uk/news/politics/tony-blair/8272699/Iraq-War-timelineof-Tony-Blairs-role.html, accessed on 6 April 2014. 
the UK government does not commit acts of terror if it is an act committed by itself (this is regardless whatever the act may be). However, such a proposal would also legitimize Libya's actions ${ }^{21}$ or even the Bali Bombing and the 9/11 Incident as well if the allegations was true that they were inside jobs. $^{22}$

In the international law regime, the determining factor may be the element of 'manifest violation of the UN Charter' which will be explained later. However, the aforementioned analysis has given some examples how acts of terror can be attributable to states (and therefore, state actors), and thus possibly satisfying one requirement of the Crime of Aggression.

\section{2) Gaps in the Law: Eluding Capture}

It may seem that State acts of terror in form of aggression might easily "check the boxes" of the Elements of Crime of Aggression. However, the fact that such act is committed by States would present different kinds of challenges.

The fact that the ICC relies on the cooperation of States to surrender the suspects is a problem in itself. ${ }^{23}$ The "leadership requirement" suggests that the crime can only be committed by high state officials, who are not known to be fond of surrendering. For example, Omar Al Bashir who is also protected by other States during visits (not for aggression, but example of head of State refusing to surrender despite ICC arrest warrant). ${ }^{24}$

Further, heads of States enjoy immunity from criminal jurisdictions from customary international law, ${ }^{25}$ despite claims of exception for perpetrators of the most serious crimes of international law. ${ }^{26}$ The ICCSt seems to dismiss immunity in Article 27 , but gives leeway in other places.

The USA, invoking Article 98 of the ICCSt, up to December 2006 has signed over one hundred agreements with other states to not surrender persons to the ICC including forty six ICC State Parties. ${ }^{27}$ They even withdrew financial aid from twenty four ICC State Parties who refused to sign these agreements. ${ }^{28}$ This is because the USA officials are afraid of prosecutions, ${ }^{29}$ which is a well-founded fear (e.g. Iraqi invasion, and torture to Iraqi prisoners). ${ }^{30}$ The ICC has jurisdiction over crimes committed in the territory of State Parties ${ }^{31}$ so the USA is not entirely safe by not being a member.

Bearing this in mind, some states signing the bilateral agreements are State Parties to the ICC. Certainly, if these kinds of agreements are made between State Parties,

Jacqueline S. Hodgson and Victor Tadros, Op.cit., p.523.

22 Bali Bombing: Centre for Research on Globalization, "US-Australia Coverup: Was Al-Qaeda Behind the 2002 Bali Bombing?", http://www. globalresearch.ca/us-australia-coverup-was-al-qaeda-behind-the-2002-bali-bombing/5307992, accessed on 6 April 2014. See also 9/11: Dailymail, "Fury as Academics Claim 9/11 was 'Inside Job", http://www.dailymail.co.uk/news/article-403757/Fury-academics-claim-9-11inside-job.html, accessed on 6 April 2014.

23 Part 6 of the ICCSt.

24 Human Rights Watch, “Chad: Don't Welcome Back Al-Bashir”, http://www.hrw.org/news/2013/04/09/chad-don-t-welcome-back-al-bashir, accessed on 10 April 2014.

25 Arrest Warrant of 11 April 2000 (Democratic Republic of the Congo v. Belgium), Judgment, I.C.J. Reports 2002 , p. 3.

Ibid, dissenting opinions of Judge Khasawneh and Judge Ad-Hoc Van den Wyngaert.

27 Coalition for the International Criminal Court, "Status of US Bilateral Immunity Agreements", http://www.iccnow.org/documents/CICCFS_ BIAstatus_current.pdf, accessed on 10 April 2014.

28 Ibid

29 Paul C. Szasz, “The United States Should Join the International Criminal Court”, US Air Force Journal of Legal Studies, Vol. 9, 1998-1999, p.13.

30 Dailymail, "British Forces 'Witnessed Electric Shocks, Beatings, and Dog Kennel Torture of Iraqi Prisoners in Secret US Prison in Baghdad", http://www.dailymail.co.uk/news/article-2302646/British-forces-witnessed-torture-Iraqi-prisoners-secret-US-prison-Baghdad.html, accessed on 10 April 2014.

31 Article 12(2)(a) of the ICCSt. 
then such agreements are incompatible with the object and purpose ${ }^{32}$ as well as these States" obligations under the ICCSt. ${ }^{33}$ However, if such an agreement was concluded between a State Party and a non-State Party, provisions of the ICCSt cannot apply to that non-State. ${ }^{34}$

\section{b. De Facto Control}

Complication rises regarding persons with de facto control despite absence of de jure position, since the wording of the said provision focuses on actual effective control rather than that of formal capacity. ${ }^{35}$ There are groups labelled as terrorists who are not within the formal structure of a State, but informally part of it. The ILC Articles on State Responsibility 2001 (Draft Articles) Article 5-9 and 11 gives a set of actions attributable to state despite not conducted by state organs. But can the leaders of such terrorists groups be charged with Crimes of Aggression?

\section{1) Two Extremes Same Verdict: Ezzeddeen al-Qassam Brigades (EQB) and AQ}

An example is Mohammed Deif, the current leader of EQB of Palestine. This group, declared as a terrorist group by some other countries e.g. the USA, ${ }^{36}$ is a military wing of Hamas..$^{37}$ However, they have their own structure, leadership, and generally independent in planning. ${ }^{38}$ Hamas, governing the Gaza Strip, ${ }^{39}$ is an important political entity in Palestine. ${ }^{40}$ Therefore, the complicity in aim and support would classify actions of EQB as an act attributable to a State as per Article 11 of the Draft Articles. This can fit the EQB in the category of "[...] armed bands, groups, irregulars, or mercenaries, which carry out acts of armed force [...]" in the ICCSt. $^{41}$ That same provision also stipulates "[...] to amount to the acts listed above [...]", while the EQB (in consonant with Hamas) have been noted to conduct many attacks including suicide bombings against Israeli civilians and military targets ${ }^{42}$ possibly amounting to an act of aggression as per Article $8 b i s(2)(b)$. While the acts of EQB can be attributable to Palestine, would Muhammad Deif (as a non-State actor) be liable for the Crime of Aggression?

If discussed in the context of the previous subsection on de jure control, the case may (to some extent) be analogous the Lockerbie by drawing possible responsibilities between the acts of EQB and Ismail Haniyeh -Gaza Prime Minister and Leader of Hamas. It may be more elusive, since the acts of EQB have some degree of independence from Hamas but still EQB's acts are attributable to Palestine as per Article 11 of the Draft Articles.

Article $8 b i s(2)(\mathrm{g})$ does provide the possibility for non-state (irregular) armed groups to commit an act of aggression when they are sent by or on behalf of the state. However, Gillet argued that the leaders of

Preamble paras 4 and 5 of the ICCSt.

Article 89(1) of the ICCSt.

Article 34 of the Vienna Convention on the Law of Treaties (1969).

Report of the Special Working Group on the Crime of Aggression (SWG) of 2009, Para. 25.

US Department of State: Office of the Coordinator for Counterterrorism, "Country Reports on Terrorism 2004", http://www.state.gov/ documents/organization/45313.pdf, accessed on 6 April 2014.

Ezzedeen Al-Qassam Brigades Official Website, “About Us”, http://www.qassam.ps/aboutus.html, accessed on 6 April 2014.

38 Ilana Kass and Bard O’Neil. 1997, The Impact of Israeli and Palestinian Rejectionism on the Peace Process: The Deadly Embrace, University of America Press, Maryland, p.267.

39 Hurriyet Daily News, "Hamas Announces Cabinet Reshuffle in Gaza", http://www.hurriyetdailynews.com/hamas-announces-cabinetreshuffle-in-gaza.aspx?pageID $=238 \& n I D=29198 \& N e w s C a t I D=352$, accessed on 6 April 2014 .

40 Al Arabiya, "Fatah, Hamas Agree to Form Palestine Unity Government", http://english.alarabiya.net/en/News/middle-east/2013/05/15/ Fatah-Hamas-agree-to-form-Palestinian-unity-government.html, accessed on 6 April 2014.

$41 \quad$ Article $8 b i s(2)(\mathrm{g})$ of the ICCSt.

42 US Department of State: Office of the Coordinator for Counterterrorism, Loc.cit. 
these non-State armed groups cannot be liable, because the requirement is for the leader to "[...] exercise control over or to direct the political or military action of a State $[\ldots] ",{ }^{43}$ and to include these non-State group leaders would require an amendment to that provision to include " $[\ldots]$ or non-State actor $[\ldots] " .{ }^{44}$

There is some truth in Gillet's argument. If we refer to the SWG report in 2009 , it gives an example of the 'Industrialists' to describe a non-State actor committing a Crime of Aggression ${ }^{45}$ citing the Farben Case $^{46}$ and Von Leeb Case, ${ }^{47}$ essentially opens the possibilities of private economic actors committing aggression, provided they had: knowledge, ability to shape or influence the policy, and to act in furtherance of the policy. ${ }^{48}$ This case law is a reference of a nonState actor but the Act of Aggression was still a military action of a State.

However Gillet's argument may sound weaker in context of EQB. To understand this, we will need to first look at the AQ in the 9/11 Incident which Gillet used as ground example for his analysis.

The 9/11 Incident was an attack to the USA by foreign nationals. ${ }^{49}$ The UNSC issued Resolutions 1368 and 1373 mentioning that such acts of terror triggers the inherent right of individual or collective self-defence. Deducing from Article 51 of the UN Charter, this particular terrorist attack is declared as an armed attack.

The USA invasion to Afghanistan treated both the Taliban regime and AQ alike, ${ }^{50}$ but the Taliban has no links to AQ. The Taliban does not support or endorse the goals of AQ in calling for and conducting international terrorism, ${ }^{51}$ but refused to surrender Osama bin Laden (OBL) simply due to customs of being a good host. ${ }^{52}$ Therefore, while the 9/11 incident may amount to an act of aggression, it is not a Crime of Aggression because: (1) not attributable to a State, and (2) OBL also has no control over Afghanistan military. ${ }^{53}$

However, Gillets argument works in a hypothetical situation where Taliban can be proven to have sufficient control over AQ (maybe leader of Taliban can be charged with Crimes of Aggression, but not OBL). ${ }^{54}$ This may, be analogous to the situation of EQB. But does the EQB count as "state military power"? If it does, then Mohammed Deif can commit Crime of Aggression. However, it will then be an example more distinct to the AQ and Taliban, and might fall under the previous subsection on de jure control instead.

Article 43(1) of the Additional Protocol I to the Geneva Conventions 1949 (1977), consonant with customary international law, sees that an armed force includes all organized armed groups under command of

\footnotetext{
Article 8 bis(1) of the ICCSt, with emphasis added.

Mathew Gillet, Op.cit., pp.839-840

Report of the Special Working Group on the Crime of Aggression (SWG) of 2009, Ibid.

USA v. Krauch, et al., Trial Judgment, Nuremberg Military Tribunals Under Control Council Law No. 10 (1952).

USA v. von Leeb, et al., Trial Judgment, Nuremberg Military Tribunals Under Control Council Law No. 10 (1950).

Von Leeb Case at paras 488-489, and Farben Case at paras 1108

The 9/11 Commission, "The 9/11 Commission Report", http://govinfo.library.unt.edu/911/report/911Report.pdf, accessed on 6 April 2014.

Alex Strick van Linschoten and Felix Kuehn, "Separating the Taliban from Al-Qaeda: The Core of Success in Afghanistan". http://cic.es.its. nyu.edu/sites/default/files/gregg_sep_tal_alqaeda.pdf, accessed on 6 April 2014.

Ibid, see also: Simon Franzen, "Unity in Terrorism: the Relationship Between Al-Qaeda, the Taliban and Militants in Pakistan", http://instmed. org/wp-content/uploads/2012/10/Al-Qaeda-and-the-Taliban.pdf, accessed on 6 April 2014.

Louis Doswald-Beck, and Jean-Marie Haenckarts, 2005, ICRC Customary International Humanitarian Law, Vol I: Rules, Cambridge University Press, Cambridge, pp.14-15.
} 
a party including both regular and irregular groups. ${ }^{55}$ The facts become murkier since Palestine does not even have an actual organized army, ${ }^{56}$ so technically all fighting forces of Palestine (Hamas, EQB, Islamic Jihad, etc) are irregular forces anyways.

However, the language of Article 8bis(2) seems to make a distinction between provisions relating acts by "armed forces" (in Article $8 b i s(2)(a)-(f))$ and "irregular armed forces" (in Article 8bis $(2)(\mathrm{g})$ ). Therefore the EQB is a military group that operates to some degree of relation to Hamas as a resistance group, but not with the Palestinian Government. Muhammad Deif therefore cannot be charged with the Crimes of Aggression. It is Ismail Haniyeh who might be prosecuted for EQB's acts, but only if he commanded it.

In case of AQ, can we agree with Gillet that OBL cannot be held liable for the 9/11 Incident even if the Taliban had control over $\mathrm{AQ}$ ? This depends on the relation between the Taliban, AQ, and OBL. If the AQ is a Taliban subordinate, then it is true that OBL cannot be held accountable for the 9/11 Incident. Instead, Mohammed Omar (Taliban leader) might be prosecuted for it if he ordered the attack - which he didn't. ${ }^{57}$

However if the OBL was respected enough to actually be part of the Taliban high command and governance of Afghanistan at that time and de facto satisfying the "leadership" requirement, then he could be charged with the Crime of Aggression.

\section{2) Gap in Law: Silence of International Instruments}

There have been prosecutions undergone in domestic courts for the suspects related to the 9/11 incident, among them is the trial of Zacarias Moussaoui. ${ }^{58}$ The first (out of six) counts to Moussaoui is the closest similar to the Crime of Aggression (trans-boundary terrorism), ${ }^{59}$ but that is stretching too far. There has been no indictment against these terrorists for an actual Crime of Aggression.

On the international level, these terrorist acts may classify as crime against humanity in form of "murder", 60 "persecution" 61 (the AQ declare to target Christians and Jews) ${ }^{62}$ and "other inhumane acts" (explained in the next section). ${ }^{63}$ There is no requirement for the perpetrator to be a State actor, and the element of "widespread or systematic" is alternative and not conjunctive. ${ }^{64}$ The "widespread" element means "[...] massive, frequent, large scale action, carried out collectively with considerable seriousness and directed against a multiplicity of victims [...]" ${ }^{\prime 65}$ The magnitude of $9 / 11$ is very serious (explained in the next section), and AQ also committed numerous others attacks including the first World Trade Center attack (1993), etc. ${ }^{66}$ The element of "systematic" is the organized nature of the acts of violence ${ }^{67}$ including political objective, ${ }^{68}$ which AQ has.

\footnotetext{
56 Anthony H. Cordesman, "Palestine Forces: Palestinian Authority and Militant Forces" http://csis.org/files/media/csis/pubs/060209_ palestforces.pdf, accessed on 7 April 2014.

Alex Strick van Linschoten and Felix Kuehn, Loc.cit.

USA v. Zacarias Moussaoui, Judgment, Eastern District of Virginia, United States District Court (2006).

Ibid.

Article 7(1)(a) of the ICCSt.

Article $7(1)(\mathrm{h})$ of the ICCSt

Osama bin Laden, et al., "Nass Bayan al-Jabhah al-Islamiyah al-Alamiyah li-Jihad al-Yahud wa-al-Salibiyin", http://www.library.cornell.edu/ colldev/mideast/fatw2.htm, accessed on 10 April 2014.

Article 7(1)(k) of the ICCSt.

Article 7(1) of the ICCSt.

Prosecutor v. Akayesu, Trial Judgment, at the International Criminal Tribunal for the former Yugoslavia (1998), para 580.

66 CBN News. "Al Qaida Timeline: Plots and Attacks", http://www.nbcnews.com/id/4677978/ns/world_news-hunt_for_al_qaida/t/al-qaidatimeline-plots-attacks/\#.UObI4PldWSo, accessed on 10 April 2014.

67 Prosecutor v. Kunarac, Appeals Judgment, at the International Criminal Tribunal for the former Yugoslavia (2002), para 94.

68 Prosecutor v. Blaskic, Trial Judgment, at the International Criminal Tribunal for the former Yugoslavia (2000), para 203.
} 
However, if their attacks indeed amount to acts of aggression other than "only" crimes against humanity, then merely prosecuting the latter is not enough. It is not impossible for one act to constitute two (or more) separate crimes, and pursuing only one is insufficient for justice and doesn't reflect the extent of the defendant's culpability. ${ }^{69}$ Therefore, the inability of the ICC to bring these terrorist groups to justice for the acts of aggression is a gap, leaving only the national law system to deal with it.

Even then, not all national laws can capture the "aggressio" character of these kinds of attacks. In UK and Indonesian law, ${ }^{70}$ there are no provisions that talk specifically about trans-boundary acts of terrorism. The Crime of Aggression is not a punishable offense either in those national laws, so there is a gap leaving the acts of terrorism by aggression unpunished.

3. "Manifest Violation of the UN Charter" Requirement

"[...] by its character, gravity and scale, constitutes a manifest violation of the Charter of the United Nations.", ${ }^{71}$ also the fifth element of the Crime of Aggression according to the ICC Elements of Crime, brings difficulties.

Gillet describes the 'character' component of the aggression as the motivation behind the attack, which may affect the lawfulness of the act. ${ }^{72}$ Certain motives may preclude unlawfulness, such as an act of self-defence. ${ }^{73}$

The "scale" component would refer to the magnitude of the aggression by means used by the aggressor, e.g. number of force, used weaponry, duration, etc. ${ }^{74}$ In this component, there would be a difference in viewing a full scale military invasion towards Iraq ${ }^{75}$ and two Russian fighter jets 'passing through' Japan. ${ }^{76}$

The final component, "gravity", is the extent of destruction and damage caused by the aggression. ${ }^{77}$ The ICC Office of the Prosecutor (OTP) considers this as well generally in determining "gravity of crime". ${ }^{78}$ Further, the OTP declared that a relatively small number of victims is would not satisfy the "gravity" requirement despite the strong indication of a crime under the ICC jurisdiction. ${ }^{79}$

Especially in context of the act of aggression, this overlap would seem to meet common sense as a larger scale of attack may necessarily result in greater destruction. Although it is not impossible either for a large scale aggression to result in low or even zero destruction, such as the recent Russian invasion to Ukraine with a heavily armed force of around twenty five thousand soldiers. ${ }^{80}$ After all, the act of aggression does not necessarily have to include an "attack" (see Article 8bis[2][a], "The invasion or attack..."). ${ }^{81}$

Bear in mind also a conjunctive "and" is used in this requirement, as emphasized in Point 7, Annex III of Resolution RC/Res.6 (2010). Can terrorist attacks fulfil these components?

\section{a. Terrorism by Non-State Actors \\ The 9/11 Incident might display itself as an example of a terrorist attack that does fulfil all components. There is no question on the scale and gravity of attack that destroyed}

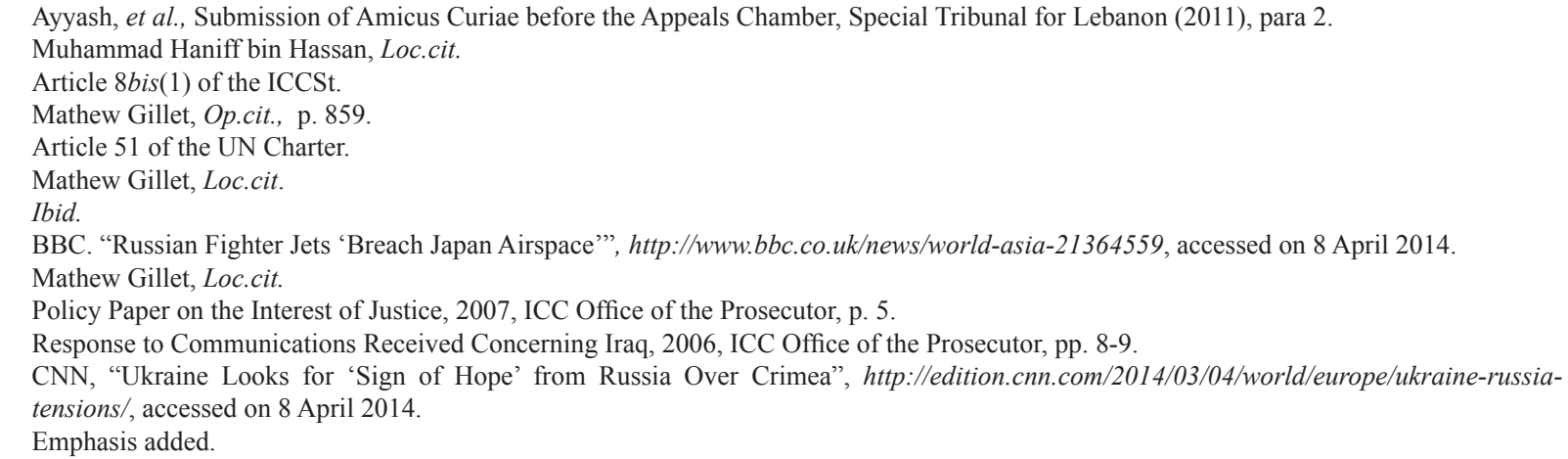


the WTC, killing almost three thousands and injuring many more. ${ }^{82}$ There is no question on the character of the attack either, OBL clearly intended to attack the USA using revenge and religion as excuses. ${ }^{83}$ The magnitude of the incident was such that the UNSC declared it an act of aggression that triggers rights to self-defence. ${ }^{84}$

In case of EQB, they do not seem to satisfy the components. While the rocket attacks to Israel territory during non-clash times may be illegal act, but armed violence has been there for a long time. Bearing in mind the situation of Gaza and Israel in general and not to mention the history of the conflict ${ }^{85}$ (without implying any legality of the rocket attacks under IHL), it is more difficult to actually conclude it as an act of aggression rather than part of an ongoing armed conflict (jus in bello applies). ${ }^{86}$ Having that said, the character itself may be questionable since it might not be a breach of jus ad bellum.

The scale and gravity of attacks as well are minimal, as the rocket attacks to Israel territory since 2001 have "only" resulted in 64 deaths (average of 4.9 deaths per year until March 2014), with a majority of instances reported without any victims or casualties. ${ }^{87}$ These kinds of "minor incursions" with very minimum impact are usually termed as "measures short of war". ${ }^{88}$ Without implying the legality of such acts, this is something lesser in scale and gravity as compared to what one would usually refer to as "war". 89
This is the collective attack from the entire Gaza, while the EQB is just one group among so many others (it is unclear which of the attacks are actually carried out by the EQB). Therefore it is not difficult to see that at least the scale and gravity of the attacks by the EQB would not satisfy a severity that would fall under the ICCSt's requirement.

However, a different way of reading the situation may result in more difficult considerations. The impacts of these rocket attacks from Gaza go beyond physical damage. These rocket attacks were meant to terrorize and bring fear to the Israeli civilians surrounding Gaza, ${ }^{90}$ which studies have shown to cause concrete implications such as an increase in Post Traumatic Syndrome Disorder ${ }^{91}$ and miscarriages. ${ }^{92}$

It has been mentioned that creating terror and fear is a subjective element of terrorism. In fact, as the name 'terrorism' suggests, the subjective element may exactly be the main point. The rising of such a climate may, to some extent, amount to a deprivation of fundamental human rights. This could be seen in: The Universal Declaration of Human Rights of 1948 (UNDHR) in the preamble para 2 and Article 3, and the International Covenant on Civil and Political Rights of 1966 (ICCPR) in the preamble para 4 and Article 9(1). Causing such deprivation of rights might classify as a crime against humanity, in form of "other inhumane acts" which can basically be a deprivation of

\footnotetext{
The 9/11 Commission, Op.cit., pp. 285-311

CBCNews, "Bin Laden Claims Responsibility for 9/11", http://www.cbc.ca/news/world/bin-laden-claims-responsibility-for-9-11-1.513654, accessed on 8 April 2014. See also Simon Franzen, Loc.cit. UN Security Council Resolutions 1368 and 1373 (2001).

Human Rights Council, Report of the United Nations Fact-Finding Mission on the Gaza Conflict, No. A/HRC/12/48 (2009), p. 408

Ibid, p.159; and applicability of IHL since the start of armed conflict (ICTY: Tadić Trial Judgement, IT-94-1-T (7 May 1997) para 561.)

Israel Ministry of Foreign Affairs. "Rocket fire from Gaza and Palestinian ceasefire violations after Operation Cast Lead", http://www.mfa.gov. il/mfa/foreignpolicy/terrorism/pages/palestinian_ceasefire_violations_since_end_operation_cast_lead.aspx, accessed on 9 April 2014.

Josef Mrázek, "Armed Conflicts and the Use of Force", Czech Yearbook of international Law, Vol. 1, November, 2010, p. 101.

Ibid.

Human Rights Council, Op.cit., p. 32.

Haaretz, "Almost Half of Sderot Preteens Show Symptoms of PTSD", http://www.haaretz.com/news/diplomacy-defense/israeli-surveyalmost-half-of-sderot-preteens-show-symptoms-of-ptsd.premium-1.479113, accessed on 9 April 2014.

92 Jerusalem Post, "Report: Missiles in Sderot Increase Miscarriages", http://www.jpost.com/Health-and-Science/Report-Missiles-on-Sderotincrease-miscarriages, accessed on 9 April 2014.
} 
human rights in ICCPR and UNDHR (along with other elements inter alia widespread or systematic attack as mentioned in previous section). ${ }^{93}$

However, while acts of terrorism can possibly classify as a crime against humanity, the real question is this: can this "terroreffect" of EQB attacks contribute to the scale and gravity of the act thus making it an act of aggression?

Despite popular view that might consider the "terror-effect", there is no clear basis to draw such conclusion. Some reading towards Articles 8bis(1) and 17(1)(d) of the ICCSt may suggest that the measurements can be beyond direct physical destruction. McDougal suggested geopolitical concerns to indicate the extent of the implications of a certain act of aggression, ${ }^{94}$ such as an execution of the President of another State by a three man team -a small scale attack but can have big geopolitical implications. ${ }^{95}$ 'Fear' has been an element that is not new to war, but traditionally it is seen as an element of refugee status. ${ }^{96} \mathrm{It}$ is the stream of refugees that is generally seen as one of the indicators of the gravity of a conflict ${ }^{97}$-not the actual fear itself.

To be fair, the 9/11 Incident did change the world and how it views international terrorism. ${ }^{98}$ It even changed a major part of international law when it triggered the UNSC to do unprecedented acts (legislates binding rules for all States, ${ }^{99}$ etc). However, the actual scale of the 9/11 Incident perhaps explains how such reactions have occurred. The gravity of the physical damage alone may be seen as extreme in itself, and not to mention the fear that spread afterwards.

However, to imply that this 'terroreffect' can be assumed to directly escalate the level of gravity of other (lesser) terrorism incidents, like the acts of the EQB, it may be too far. This may serve as possible development of the law, but in international criminal law what is relevant is only the law as it is (see: Article 22[2] of the ICCSt). Therefore, using the law as it is, this fear cannot (yet) be accounted into the gravity towards an act of aggression.

On another level, even if we assume that the "terror-effect" does contribute to the gravity, a second problem is present: scale. While the gravity is increased by the said "terror-effect", the attack still remains as small scale attacks. Bearing in mind that "character", "scale", and "gravity" are conjunctive components, the requirements are not satisfied. This is similar to McDougal's president execution example as well since the gravity may be large but the scale of attack remains small. ${ }^{100}$ In case of the EQB, even if the terror caused to the surrounding Israeli territories escalate the gravity of the situation, yet the scale of attack remains as a series of occasional small rocket attacks causing insignificant damage.

\section{b. Terrorism by State Actors}

It has been explained in the previous section how States can do certain manoeuvers

Kupreskic Trial Judgement, before the International Criminal Tribunal for the former Yugoslavia (2000), para 566.

Carrie McDougal, 2013, The Crime of Aggression Under the ICCSt of the International Criminal Court, Cambridge University Press, New York, p. 128.

Ibid.

96 Article 1(A)(2) of the Convention Relating to the Status of Refugees (1951).

97 Christine Bell, "Negotiating Justice? Human Rights and Peace Agreements", http://www.ichrp.org/files/reports/22/128_report_en.pdf, accessed 24 July 2014.

98 Vincent-Joel Proulx, "Rethinking the Jurisdiction of the International Criminal Court in the Post-September 11th Era: Should Acts of Terrorism Qualify as Crimes Against Humanity?" American University International Law Review, Vol. 19, No. 5, 2004, p. 1025.

99 Resolution 1373 (2001), see also: Alan Boyle and Christine Chinkin, 2007, The Making of International Law, Oxford University Press, New York, pp. 7-8.

100 Carrie McDougal, Loc.cit. 
to elude themselves from responsibility for acts of aggression, which can be as blunt as simply refusing to surrender until more "legal" ways such as the USA bilateral agreements. There are also other gaps in the law at the 'manifest violation' test which State actors can play with to elude themselves from responsibility.

Previously, McDougal has shown an example of acts of aggression by states (president execution) which do not rise to Crime of Aggression due to lack in scale despite impact. This is also something that is available for States to 'manage' in order to elude themselves from responsibility. A possible example to that is the alleged USA involvement in terrorist attacks to influence the politics in Italy, aiming to halt the leftist party in the 1970s (allegedly, as this matter has yet to be properly investigated). ${ }^{101}$ Even if this attack were to be attributed to the USA, it could hardly satisfy the 'gravity' criteria as the victims were only sixteen people. ${ }^{102}$

However, the gap in the 'character' is unique to States, as they would require special international fora to utilize. This particular component, when faced with the threshold (i.e. manifest violation of the UN Charter) will find ways to be eluded. It has been explained how the component of 'character' is a question of motive, whether or not the use of force was justified. The example that was used earlier was acts of self-defence which is justified under Article 51 of the UN Charter.

The UNSC would have a big role in this matter, since the act of aggression is a breach of peace while the UNSC has a role of maintaining international peace and security ${ }^{103}$ Under Article 42 of the UN Charter, the UNSC can utilize force or authorize the use of force. It is generally understood that this kind of use of force is consistent with the UN Charter, as Article 42 is under Chapter VII which may circumvent the prohibition against the use of force as per Article 2(7) of the UN Charter. A UNSC Resolution can therefore preclude a particular act that would normally classify as an act of aggression, into a proper and legal motivation and thus not satisfying the 'character' component. An example to this would be the first invasion to Iraq in 1991, which was authorized by UNSC Resolution No. 678 (1990). ${ }^{104}$

On the other hand, the UNSC can also declare a particular use of force as illegal. An example to that would be the Iraq invasion to Kuwait in 1990, which the UNSC declared its illegality through UNSC Resolutions 660 and 661 (both in 1990). When there is such declaration of illegality, certainly there is big evidence that the "character" component is satisfied to be a "manifest breach of the UN Charter".

However, what happens in absence of a UNSC explicit approval/condemning is a more elusive. It is not impossible for certain states to commit acts that might ordinarily amount to an act of aggression, but the UNSC does not issue any resolution -not because it did not really amount to a threat but because of the veto. An example to this is, again, the 2003 Iraq invasion.

The legality of this invasion was very dubious. The USA and UK armies relied on past UNSC Resolution 678 (1990), claiming that the conditions for authorization

101 The Guardian, "Terrorists 'Helped by CIA' to Stop Rise of Left in Italy", http://www.theguardian.com/world/2001/mar/26/terrorism, accessed on 11 April 2004, for other alleged inter-State 'terrorist operations' by the USA see also: Centre for Research on Globalization, "America Is Running the World Largest Terrorist Operation", http://www.globalresearch.ca/america-is-running-the-worlds-largest-terroristoperation/5339835, accessed on 12 April 2014.

02 Ibid.

103 Article 24(1) of the UN Charter.

104 John Yoo, "International Law and the War in Iraq", American Journal of International Law, Vol. 97, July, 2003 , p. 564. 
of authorization of the use of force against Iraq was somewhat 'relived'. ${ }^{105}$ Resolution 678 (1990) gives authority to use force if Iraq fails to fulfil the cease-fire provisions, and Iraq did so then USA and UK sent their forces in 1991. ${ }^{106}$ Now that in 2002-2003 Iraq is allegedly breaching that same 'cease-fire provision' (specifically the disarmament and weapons inspection requirement), ${ }^{107}$ the USA and UK attacked again based on the same Resolution 678.

One on hand, the argument that USA and UK submitted was based on a UNSC Resolution which, as aforementioned, may preclude the unlawfulness of the use of force if the argument were accepted. Not to mention, this invasion was not condemned by the UNSC.

On the other hand, Resolution 678 (1990) was made in the context of the Iraq invasion to Kuwait. Therefore, it should be a whole different context for 2003 that does not at all involve Kuwait. Further, a proposal for an authorization was attempted but withdrawn as it would have only secured four votes in the UNSC. ${ }^{108}$ A number of UNGA members were also invited to the UNSC to give their views, which an overwhelming majority of them stating that there is no actual threat to international peace and security to justify any form of military action towards Iraq. ${ }^{109}$ It is also inconceivable for the UNSC to even think of passing a resolution to condemn the Iraq invasion, since both main actors of that invasion (USA and UK) has veto rights.

An argument of anticipatory selfdefence was also submitted by the USA and UK, which has to be proven 'instant, overwhelming, leaving no choice of means, and no moment for deliberation', as required in the Caroline Test. ${ }^{110}$ Arguing against this claim, it has already been mentioned how there is an overwhelming number of states from the UNGA and UNSC disagreeing to the state of such threat towards international peace and security.

However, no matter how overwhelming one side of the argument may seem, even scholars who argue against the legality of the Iraq invasion admits that the arguments for the legality cannot be fully dismissed. ${ }^{111}$ This is while Article 8bis(1) requires the violation of UN Charter to be 'manifest'. Therefore, it is not impossible that these manoeuvers are used by certain States to get away with terrorism in form of aggression. This is especially true for States who have veto rights to render UNSC Resolutions impossible to declare an authoritative unlawfulness of certain actions.

\section{Conclusion}

Exploring the connection between terrorism and aggression reveals a number of things. The first is the fact that it is not impossible for States to commit acts of terror in form of aggression.

The 2003 invasion Iraq may serve as an elusive example, but it is not entirely irrelevant to discuss terrorism by State with current definitions being so broad. This kind of terrorism may very well generally fall under the Crime of Aggression to some extent, however there are gaps in the law that certain States can exploit to avoid responsibilities. These gaps are: the element of "manifest violation

108 The Guardian, "Ten Days to War", http://www.theguardian.com/world/2008/mar/08/iraq.unitednations, accessed on 12 April 2014.

109 Alex Bellamy, "International Law and the War in Iraq", Melbourne Journal of International Law, Vol. 4, No.2, 2003, p. 519

110 Keith Petty, "Criminalizing Force: Resolving the Threshold Question for the Crime of Aggression in the Context of Modern Conflict", Seattle University Law Review, Vol. 33, 2009, pp. 113-134.

111 Claus Kress, "Time for Decision: Some Thoughts on the Immediate Future of the Crime of Aggression: A Reply to Andreas Paulus", The European Journal of International Law, Vol. 20, No. 4, 2010, pp.1141-1142. See also, Mathew Gillet, Op.cit., pp. 849-850. 
of the UN Charter" in terms of "characteristic", as well as bilateral agreements under Article 98 of the ICCSt.

The more popular forms of terrorism would be by non-State actors such as the AQ. However, it is near impossible for these kinds of terrorists to be charged with Crimes of Aggression especially on the 'leadership' requirement. Further, the 'scale' and 'gravity' components of the 'manifest violation of the UN Charter' element are also hard to fulfil. Although the acts of terror itself, probably as a crime against humanity at best, might be punished. However, the 'act of aggression' that these terrorists commit would remain unpunished, leaving another gap in the law from the current reality of what terrorists are capable of doing.

\section{BIBLIOGRAPHY}

\section{A. Books}

Boyle, Alan and Christine Chinkin, 2007, The Making of International Law, Oxford University Press, New York.

Doswald-Beck, Louis, and Jean-Marie Haenckarts, 2005, ICRC Customary International Humanitarian Law, Vol I: Rules, Cambridge University Press, Cambridge.

Kass, Ilana and Bard O'Neil. 1997, The Impact of Israeli and Palestinian Rejectionism on the Peace Process: The Deadly Embrace, University of America Press, Maryland.

McDougal, Carrie, 2013, The Crime of Aggression Under the ICCSt of the International Criminal Court, Cambridge University Press, New York.

Sassoli, Marco et al,. 2006, How Does Law Protect in War: Volume I (Outline of International Humanitarian Law) Third Edition, International Committee of the Red Cross, Geneva.

\section{B. Anthology}

Walter, Christian, "Defining Terrorism in National and International Law", in Christian Walters et al, 2004, Terrorism as a Challenge for National and International Law: Security versus Liberty? Sprinter, Heidelberg

\section{Journal Articles}

Bassiouni, M. Cherif. "International Crimes: Jus Cogens and Obligatio Erga Omnes", Law and Contemporary Problems, Vol. 59, No.4, 1996.
Bellamy, Alex, "International Law and the War in Iraq", Melbourne Journal of International Law, Vol. 4, No.2, 2003.

Gillet, Mathew, "The Anatomy of an International Crime of Aggression at the International Criminal Court", International Criminal Law Review, Vol. 13, No. 4, 2013.

Hare, Angela, "A New Forum for the Prosecution of Terrorists: Exploring the Possibility of the Addition of Terrorism to the ICCSt's Jurisdiction", Loyola University Chicago International Law Review. Vol. 8, No.1, 2010.

bin Hassan, Muhammad Haniff, "Imam Samudra's Justification for Bali Bombing", Studies in Conflict and Terrorism, Vol. 30, Iss.12, 2007.

Hodgson, Jacqueline S. and Victor Tadros, "The Impossibility of Defining Terrorism", New Criminal Law Review: An International and Interdisciplinary Journal, Vol. 16, No. 3, August, 2013.

Kress, Claus, "Time for Decision: Some Thoughts on the Immediate Future of the Crime of Aggression: A Reply to Andreas Paulus", The European Journal of International Law, Vol. 20, No. 4, 2010.

Mrázek, Josef, "Armed Conflicts and the Use of Force", Czech Yearbook of international Law, Vol. 1, November, 2010.

Petty, Keith, "Criminalizing Force: Resolving the Threshold Question for the Crime of Aggression in the Context of Modern Conflict", Seattle University Law Review, Vol. 33, 2009.

Proulx, Vincent-Joel, "Rethinking the Jurisdiction of 
the International Criminal Court in the PostSeptember 11 th Era: Should Acts of Terrorism Qualify as Crimes Against Humanity?" American University International Law Review, Vol. 19, No.5, 2004.

Stottlemyre, Steven, "Libya and the International System: Retracing the Aftermath of the Lockerbie Bombing", Digest of Middle East Studies, Vol. 20, No.1, May, 2011.

Szasz, Paul C Paul C. Szasz, "The United States Should Join the International Criminal Court", US Air Force Journal of Legal Studies, Vol. 9, 1998-1999.

Yoo, John, "International Law and the War in Iraq", American Journal of International Law, Vol. 97, July, 2003.

\section{Internet Articles}

Al Arabiya, "Fatah, Hamas Agree to Form Palestine Unity Government", http://english.alarabiya. net/en/News/middle-east/2013/05/15/FatahHamas-agree-to-form-Palestinian-unitygovernment.html, accessed on 6 April 2014.

BBC, "Colonel Gaddafi 'ordered Lockerbie bombing", http://www.bbc.co.uk/news/ukscotland-south-scotland-12552587, accessed on 6 April 2014.

BBC. Iraq War in Figures, "Iraq War in Figures", http://www.bbc.co.uk/news/world-middleeast-11107739, accessed on 6 April 2014.

BBC. "Russian Fighter Jets 'Breach Japan Airspace", $\quad$ http://www.bbc.co.uk/news/ world-asia-21364559, accessed on 8 April 2014.

Bell, Christine"Negotiating Justice? Human Rights and Peace Agreements", http://www.ichrp. org/files/reports/22/128_report_en.pdf, accessed on 24 July 2014.

bin Laden, Osama, et al., "Nass Bayan al-Jabhah al-Islamiyah al-Alamiyah li-Jihad al-Yahud wa-al-Salibiyin", http://www.library.cornell. edu/colldev/mideast/fatw2.htm, accessed 10 April 2014 at 5.20pm

CBCNews, "Bin Laden Claims Responsibility for 9/11", http://www.cbc.ca/news/ world/bin-laden-claims-responsibilityfor-9-11-1.513654, accessed on 8 April 2014. CBN News. "Al Qaida Timeline: Plots and Attacks", http://www.nbcnews.com/id/4677978/ns/ world_news-hunt_for_al_qaida/t/al-qaidatimeline-plots-attacks/\#.U0bI4PldWSo, accessed on 10 April 2014.

CNN, "Ukraine Looks for 'Sign of Hope' from Russia Over Crimea", http://edition.cnn. com/2014/03/04/world/europe/ukrainerussia-tensions/, accessed on 8 April 2014.

Centre for Research on Globalization, "America Is Running the World Largest Terrorist Operation", http://www.globalresearch.cal america-is-running-the-worlds-largestterrorist-operation $/ 5339835$, accessed on 12 April 2014.

Centre for Research on Globalization, "US-Australia Coverup: Was Al-Qaeda Behind the 2002 Bali Bombing?", http://www.globalresearch.cal us-australia-coverup-was-al-qaeda-behindthe-2002-bali-bombing/5307992, accessed on 6 April 2014.

Coalition for the International Criminal Court, "Status of US Bilateral Immunity Agreements", $\quad$ http://www.iccnow.org/ documents/CICCFS_BIAstatus_current.pdf, accessed on 10 April 2014.

Cordesman, Anthony H, "Palestine Forces: Palestinian Authority and Militant Forces" http://csis.org/files/media/csis/pubs/060209_ palestforces.pdf, accessed on 7 April 2014.

Dailymail, "British Forces 'Witnessed Electric Shocks, Beatings, and Dog Kennel Torture of Iraqi Prisoners in Secret US Prison in Baghdad", http://www.dailymail.co.uk/news/ article-2302646/British-forces-witnessedtorture-Iraqi-prisoners-secret-US-prisonBaghdad.html, accessed on 10 April 2014.

Dailymail, "Fury as Academics Claim 9/11 was 'Inside Job'", http://www.dailymail.co.uk/ news/article-403757/Fury-academics-claim9-11-inside-job.html, accessed on 6 April 
2014.

Ezzedeen Al-Qassam Brigades Official Website, "About Us", http://www.qassam.ps/aboutus. html, accessed on 6 April 2014.

Franzen, Simon, "Unity in Terrorism: the Relationship Between Al-Qaeda, the Taliban and Militants in Pakistan", http://instmed. org/wp-content/uploads/2012/10/Al-Qaedaand-the-Taliban.pdf, accessed on 6 April 2014.

Haaretz, "Almost Half of Sderot Preteens Show Symptoms of PTSD", http://www.haaretz. $\mathrm{com} /$ news/diplomacy-defense/israelisurvey-almost-half-of-sderot-preteensshow-symptoms-of-ptsd.premium-1.479113, accessed on 9 April 2014.

Human Rights Watch, "Chad: Don't Welcome Back Al-Bashir", http://www.hrw.org/ news/2013/04/09/chad-don-t-welcome-backal-bashir, accessed on 10 April 2014.

Hurriyet Daily News, "Hamas Announces Cabinet Reshuffle in Gaza", http://www. hurriyetdailynews.com/hamas-announcescabinet-reshuffle-in-gaza.aspx?pageID $=23$ $8 \& n I D=29198 \&$ News $C a t I D=352$, accessed on 6 April 2014.

Israel Ministry of Foreign Affairs. "Rocket fire from Gaza and Palestinian ceasefire violations after Operation Cast Lead", http://www.mfa. gov.il/mfa/foreignpolicy/terrorism/pages/ palestinian_ceasefire_violations_since_end_ operation_cast_lead.aspx, accessed on 9 April 2014.

Jerusalem Post, "Report: Missiles in Sderot Increase Miscarriages", http://www.jpost.com/Healthand-Science/Report-Missiles-on-Sderotincrease-miscarriages, accessed on 9 April 2014.

Strick, Alex van Linschoten and Felix Kuehn. "Separating the Taliban from Al-Qaeda: The Core of Success in Afghanistan". http://cic. es.its.nyu.edu/sites/default/files/gregg_sep_ tal_alqaeda.pdf, accessed on 6 April 2014.

The Guardian, "Ten Days to War", http://www. theguardian.com/world/2008/mar/08/iraq . unitednations, accessed on 12 April 2014.

The Guardian, "Terrorists 'Helped by CIA' to Stop Rise of Left in Italy", http://www.theguardian. com/world/2001/mar/26/terrorism, accessed on 11 April 2004.

The Telegraph, "Iraqi War: Timeline of Tony Blair's Role", http://www.telegraph.co.uk/ news/politics/tony-blair/8272699/Iraq-Wartimeline-of-Tony-Blairs-role.html, accessed on 6 April 2014.

\section{E. International or National Instruments and Documents}

Convention Relating to the Status of Refugees (1951).

Policy Paper on the Interest of Justice, 2007, ICC Office of the Prosecutor.

ILC Draft Code of Crimes against the Peace and Security of Mankind (1996).

ILC Articles on State Responsibility (2001).

Indonesian Anti-Terrorism Law No. 15 of 2003,

Officiating Government Regulation in Lieu of Law No. 1 of 2002.

Policy Paper on the Interest of Justice, 2007, ICC

Office of the Prosecutor

Response to Communications Received Concerning Iraq, 2006, ICC Office of the Prosecutor.

Report of the Special Working Group on the Crime of Aggression (2009).

Report of the United Nations Fact-Finding Mission on the Gaza Conflict, Report No. A/ HRC/12/48, Human Rights Council (2009).

Rome Statute of the International Criminal Court (1998).

The 9/11 Commission Report.

The Additional Protocol to the Geneva Conventions 1949 (1977).

The Geneva Conventions (1949).

UK Terrorism Act (2000).

UN General Assembly Resolution No. 3314 (1974).

UN General Assembly Resolution No. 53 (1995).

UN Security Council Resolution No. 660 (1990).

UN Security Council Resolution No. 661 (1990). 
UN Security Council Resolution No. 678 (1990).

UN Security Council Resolution No. 731 (1992).

UN Security Council Resolution No. 748 (1992).

UN Security Council Resolution No. 1368 (2001).

UN Security Council Resolution No. 1373 (2001).

US Department of State: Office of the Coordinator

for Counterterrorism. Country Reports on Terrorism 2004, April 2005.

Vienna Convention on the Law of Treaties (1969).

\section{F. Judicial Decisions and Documents}

Arrest Warrant of 11 April 2000 (Democratic Republic of the Congo v. Belgium), Judgment, I.C.J. Reports 2002.

Prosecutor v. Akayesu, Trial Judgment, at the International Criminal Tribunal for the former Yugoslavia (1998).

Prosecutor v. Ayyash et al, Submission of Amicus Curiae before the Appeals Chamber, Special Tribunal for Lebanon (2011).

Prosecutor v. Blaskic, Trial Judgment, at the
International Criminal Tribunal for the former Yugoslavia (2000).

Prosecutor v. Kunarac, Appeals Judgment, at the International Criminal Tribunal for the former Yugoslavia (2002).

Prosecutor v. Kupreskic, Trial Judgement, at the International Criminal Tribunal for the former Yugoslavia (2000).

Prosecutor v. Tadić, Trial Judgement, at the International Criminal Tribunal for the former Yugoslavia (1997).

USA v. Krauch et al Trial Judgment, Nuremberg Military Tribunals Under Control Council Law No. 10 (1952).

USA v. von Leeb et al Trial Judgment, Nuremberg Military Tribunals Under Control Council Law No. 10 (1950).

USA v. Zacarias Moussaoui, Judgment, Eastern District of Virginia, United States District Court (2006). 